\title{
Local economic development agencies and peripheral small town development: Evidence from Somerset East, South Africa
}

\begin{abstract}
The activities of Local Economic Development Agencies (LEDAs) represent a channel for place-based development. In South Africa national government has supported the expansion of LEDAs to improve the weak performance of local economic development planning, one of the cornerstones of the developmental state. This article investigates the evolution and operations of a small town LEDA which is situated in one of South Africa's peripheral regions. The local development facilitation and project work undertaken by the Blue Crane Development Agency (BCDA) in the small town of Somerset East in Eastern Cape Province is discussed. It is shown that this LEDA was innovative in development initiatives which were launched during the period 20042014 for Somerset East and its surrounds. In terms of the projects and operations of BCDA considerable effort was made to identify catalytic opportunities and to support the unlocking of projects in this small town through development facilitation and project management. Nevertheless, the evidence from this case study demonstrates that despite successes, development agencies in South Africa have a strong dependence on parent municipalities which can determine the future direction and sustainability of LEDAs.
\end{abstract}

Keywords: place-based development, local economic development, local economic development agencies,South Africa

\section{Introduction}

One of the most intractable challenges faced by national government in South Africa remains that of addressing geographically uneven patterns of development (Nel \& Rogerson, 2016a; Rogerson \& Nel, 2016b). South Africa is acknowledged as one of the most unequal countries in the world in terms of recorded levels of income and wealth (Turok \& Visagie, 2018). Its space economy reflects historically entrenched inequalities with large areas deliberately under-developed (Todes \& Turok, 2018). Currently, major differences exist in the development landscape between the country's core regions - mainly the major metropolitan centres - and the peripheral underdeveloped regions which are collectively styled as 'the distressed areas' (Rogerson \& Nel, 2016b; Rogerson, 2019). The distressed areas correspond closely to those regions of South Africa which were designated under apartheid as the Bantustans or Homelands. In terms of the settlement hierarchy the severest levels of poverty, unemployment and marginalization are evidenced in small town and rural South Africa (Nel \& Rogerson, 2005, 2007). The works of Rogerson and Nel (2016a) and of Todes and Turok (2018) provide overviews of a range of spatially targeted interventions which are designed by national government to upgrade economic development and livelihoods in peripheral regions. Alongside national government interventions seeking to achieve spatial re-balancing there are a number of 'place-based' policy interventions which are attracting an international focus (Barca et al., 2012; Rodriguez-Pose \& Wilkie, 2017). Arguably, place-based approaches "are founded on the belief that there is a need to tailor policies and strategies to 
address unique contextual conditions and reflect the opportunities, challenges and resources that characterise a given territory's ability to induce growth and development that benefits its residents" (Rodriguez-Pose \& Wilkie, 2015: 20).

In South Africa the most widespread form of place-based intervention that exists is the encouragement of local economic development planning (Rogerson, 2014). Planning for LED was applied soon after the democratic transition and represents a more localised 'place-based' intervention than the spatially targeted strategies such as those for infrastructure development (Nel \& Rogerson, 2005; Rogerson, 2014; Rogerson \& Nel, 2016a). Since the release in 1996 of the first post-apartheid National Constitution all local authorities in South Africa are obliged to engage in social and economic interventions (Nel \& Rogerson, 2005). This responsibility was reinforced and codified in the mandate for 'developmental local government' introduced in 1998 which incorporated the requirement that LED be a core component of decentralized local government planning processes. Nevertheless, it is apparent that whilst LED enjoys a high profile in development planning in South Africa its actual developmental contribution is assessed as 'sub-optimal' or 'disappointing' particularly outside of the confines of the country's well-resourced and capacitated large urban centres (Nel et al., 2009; Rogerson, 2010; Rogerson \& Rogerson, 2012; Nel \& Rogerson, 2016a, 2016b). Notwithstanding the concerted efforts put into LED interventions, several factors have undermined the general performance of LED initiatives. These include often a poor awareness of what is LED, lack of understanding of local economies, human resource capacity and budget constraints, widespread corruption linked to state capture, the targeting of unsustainable community-based interventions, weak business environments for the private sector, and the challenge of attempting to coerce market-based forces to function in spaces with the limited prospects of profitability (Nel et al., 2009; Rogerson, 2010; Rogerson \& Rogerson, 2011, 2012; Nel \& Rogerson, 2016b).

Overall, whilst South Africa is sometimes regarded as a leader within the global South concerning its establishment of LED policy and strategy, it is difficult to make the argument convincingly that its outcomes have made a significant difference in all local communities (Nel et al, 2009; Rogerson \& Rogerson, 2010; Rogerson \& Nel, 2016a, 2016b). Undoubtedly, these disappointments have been greatest in the peripheral regions and many small towns of South Africa which are the least well-capacitated and, in many cases, with limited local funding available to support LED interventions (Nel \& Rogerson, 2005, 2007; Rogerson, 2011). National government has acknowledged these shortcomings in its efforts to support LED initiatives across the country. In response it launched in 2017 a (revised draft) National Framework for Local Economic Development which is targeted to support the work of local municipalities towards attainment of the vision of "innovative, competitive, sustainable, inclusive local economies that maximize local opportunities, address local needs, and contribute to national economic development" (Walaza, 2017: 6). Innovation is a new focus in the revamping of LED policy frameworks in South Africa (Ndabeni et al., 2016; Rogerson, 2018). With a general low level of confidence surrounding local government and in particular that the practices of local government are not matching policy intent, one aspect of that revised policy framework is the role accorded to Local Economic Development Agencies or LEDAs to support enhanced economic and social development prospects particularly in the country's peripheral regions. The introduction of LEDAs into the South African development landscape as part of the developmental state as well as aspects of the unfolding operations of LEDAs are documented in a number of recent research contributions (Malefane \& Khalo, 2010; Malefane, 2011; Lawrence, 2013; Venter, 2014; Lawrence, 2016; Khambule, 2018; Lawrence \& Rogerson, 2018) 
In terms of international scholarship LEDAs are acknowledged as an institutional vehicle which potentially can be a significant contributor to place-based development (UNDP et al., 2003; Muguira, 2006; Meyer-Stamer, 2007; Canzanelli, 2008, 2009; International Link and Services for Local Economic Development Agencies, 2009; Mountford, 2009; Blakely \& Leigh, 2010; Clark et al., 2010; Canzanelli, 2011a, 2011b; Bateman, 2012; Ferrannini \& Canzanelli, 2013). Traditionally LEDAs are associated with local governments and closely aligned with locality development agendas as a key stakeholder both linked to local government as well as operating independently of it (Venter, 2014; Lawrence, 2018). The international experience shows that, irrespective of differing operational contexts, certain common objectives exist for LEDAs (International Link and Services for Local Economic Development Agencies, 2009). These include to address the challenges of marginalisation, territorial inclusion, innovation, collaborative partnerships, as well as the development of tailor-made strategies and the implementation of approaches that complement the unique context of a particular local area. As a whole, LEDAs are considered delivery agents for LED and highlighted for their strategic role in territorial development (UNDP et al. 2003; MeyerStamer, 2007; Canzanelli, 2008). The varying organisational forms of LEDAs are geared towards addressing the context of local businesses in an ever-changing LED policy environment, whilst at the same time seeking to respond to the dynamics of a complex interface between the business environment requirements on the one hand and the need to understand and appreciate the vital role and contribution of sound governance in locality development on the other. This ability to navigate between these two contexts of the private and public sector contributes to the unique features of LEDAs as well as embedding their contributions into the system of local governance (Meyer-Stamer, 2007; Canzanelli, 2008; International Link and Services for Local Economic Development Agencies, 2009; Mountford, 2009; Clark et al., 2010; Canzanelli, 2011a, 2011b; Ferrannini \& Canzanelli, 2013; Nel, 2017)

It is against a backdrop of international debates about the role of LEDAs in place-based development that the objective in this paper is to investigate the operations of one small town -based LEDA in a peripheral region of South Africa. The analysis is of the local development facilitation and project work undertaken by the Blue Crane Development Agency (BCDA) in the small town of Somerset East in South Africa's Eastern Cape Province during the period of 2004 and 2014. The BCDA operated in the Blue Crane Route Municipality (BCRM) which is one of nine local municipalities within the (mainly) rural Sarah Baartman District Municipality (formerly titled the Cacadu District Municipality). According to the 2011 census, 36002 people resided in the Blue Crane Route municipality which covers an area of $11,068 \mathrm{sq} . \mathrm{km}$. The economic base of this small town and rural locality is commercial farming with some recent growth in tourism and creative industries. The area is distinguished by a long history of socio-economic challenges and with a 31 percent unemployment rate is largely characteristic of many small towns of rural South Africa which are outside of the former Homelands. Given the rural nature of the municipality, high levels of poverty are recorded and reflected in dependency of households on government social grants as well as increased out-migration from the district. In this discussion an analysis is undertaken of the operational context of BCDA, the type of projects, how these related to the local environment, and BCDA's relationships with the parent municipality. Finally, the focus shifts to investigate the consolidation and merger of BCDA into the Cacadu District Municipality Development Agency (CDA). Source material for this research derives from documentary sources in terms of agency annual reports and internal documents from the local 
municipality; these are triangulated with detailed key stakeholder interviews which were undertaken with LEDA personnel (Mvoko, 2016a, 2016b; Wilkins \& Beech, 2016).

\section{The Blue Crane Development Agency: Establishment and planning}

In order to address economic development challenges and opportunities of the area in a structured way, the BCDA "was first registered in 2004 as a Section 21 Company and then became a municipal entity in 2006" (LED Network, 2011: 3). The BCRM approved the establishment of a local economic development agency in 2006, with the intention that this agency would serve as an invaluable resource that would assist with the unlocking of economic potential in the area and contribute to improving the socio-economic conditions across the municipality (BCDA, 2008a, 2008b). At inception of the BCDA it was linked to a long standing partnership forum of developers called the "Blue Crane Planners and Developers" who operated across the municipality as individual project implementers and partners in development (BCDA, 2011:12). This forum was supported by the municipality and tasked with the responsibility to expand its scope to include other sectors such as agriculture and tourism. It was agreed that the outcomes of this work would then be integrated into the municipality's formal Integrated Development Planning (IDP) process. In order to capture the scope of this work project feasibility studies needed to be pursued. This did, however, have a significant cost implication for an already financially challenged municipality. At this time South Africa's Industrial Development Corporation was supporting the wider roll out of development agencies in South Africa (Lawrence, 2013, 2018). It was suggested by the forum that the BCRM explore the possibility of establishing a development agency that would serve as the official platform through which these projects would be channelled and implemented. The BCDA was then introduced as a Section 21 Company in 2004 and in 2006 it became fully integrated into the formal structures of the municipality (BCDA, 2011: 12).

The IDC supported the establishment of development agencies on a number of grounds. Nel (2017) points out that local communities often do not recognize their development assets and often inappropriate strategies in local planning processes are copies from elsewhere. In small town areas municipalities often are not focused on economic potential simply because of the overwhelming problems such as addressing basic needs which leads to a (misguided) focus on poverty alleviation projects rather than sustainable and viable business opportunities ( $\mathrm{Nel}$, 2017). As an IDC funded and supported agency BCDA was regarded as a 'best practice' model by the IDC's Agency Development and Support Unit (ADS). The intention was that lessons could be drawn from the project context of the Somerset East based agency and later taken up by other similarly capacitated agencies as well as policy makers interested in the role and contribution of agencies to the local development landscape in South Africa. The formal integration of the BCDA into the local governance landscape meant that strategic facilitation and economic development expertise that was not necessarily present in the municipal structures before, could now be strategically channelled to achieve municipal development priorities in an institutionally structured way. The BCDA's aim was to support the municipality with the unlocking of development potential in the area as well as contribute towards the realisation of its economic development vision (LED Network, 2011: 3). The agency was explicit with regard to its area of focus and this was reflected in its organisational mandate which was stated as follows: "To conceptualise opportunities and facilitate macro sustainable developmental projects related to agriculture, business, renewable energy, tourism and social responsibility to the benefit of all citizens with special emphasis on job creation 
and BEE [Black Economic Empowerment] opportunities." (BCDA, 2014: 5). In addition, the BCDA vision was "to be an internationally recognised model Agency for the delivery of sustainable developmental projects in a rural context" (BCDA, 2014: 5). From its establishment the BCDA placed a strong emphasis on its role as facilitator as opposed to implementer of development projects.

At the time of the foundation of BCDA, the municipality had an operating LED unit. It is observed that the role of this LED unit was different to that of the agency in that its focus was predominantly on social projects for the youth or skills development (LED Network, 2011: 2 ). By contrast the vision of the BCDA was that it would serve as a special purpose vehicle that would add further depth to the mandate of this functional LED unit through the support of "bigger LED projects with a macro-economic long term approach" (LED Network, 2011: 2). Combined with the work of the LED unit it was envisaged that their efforts would spur significant economic development and sector-specific growth. The intention behind this distinction was that funding for these 'bigger LED projects' would be sourced independently of traditional municipal budgetary processes. This funding source would ideally come from external partners who saw value in these catalytic projects. The specific roles and contributions of both the LED unit and the LEDA for the municipality are shown on Table 1.

Table 1: The Operational Distinctions Between the LEDA and the LED Office in Blue Crane Route Municipality.

\begin{tabular}{ll}
\hline BCDA as a LEGAL ENTITY & LED as a MUNICIPAL FUNCTION \\
\hline $\begin{array}{l}\text { Agency is not part of the LED/IDP position } \\
\text { BCDA is a separate legal entity of the BCRM. }\end{array}$ & $\begin{array}{l}\text { LED component of LED/IDP position could be } \\
\text { outsourced to the BCDA for effective functioning. } \\
\text { LED/IDP is a municipal office }\end{array}$ \\
\hline BCDA is IDC funded. & LED/IDP is BCRM funded. \\
\hline BCDA is primarily responsible for macro projects & $\begin{array}{l}\text { LED/IDP is primarily responsible for IDP and LED } \\
\text { smaller projects }\end{array}$ \\
\hline $\begin{array}{l}\text { BCDA falls directly under the Mayor and council, } \\
\text { Board of directors }\end{array}$ & LED/IDP falls directly under the municipal manager \\
\hline
\end{tabular}

Source: Adapted after BCDA, 2011.

With the dominance of commercial farming in the municipal area, the intention was to concentrate on unlocking economic potential by exploring value addition to locally produced products. Accordingly, the municipality noted that they were keen to support local cluster development so as to attract external investors and in so doing add value to the municipal economic development opportunities. The growth of industrial clusters in the municipal area was also seen as one of the main objectives of BCDA and was further endorsed in the Integrated Development Plan (IDP) in which it was stated that the BCRM sought to broaden the local economy through the establishment of a strong industrial sector (BCDA, 2015). It was also further noted that this expansion of the industrial sector would contribute towards the long-term sustainability of the rural economy. The strategic focus of the implementation team was therefore to look at unlocking potential economic development in the tourism, aviation, business, agriculture, renewable energy and cultural sectors (LED Network, 2011: 3 ). These sectors were deemed relevant given the local attributes of the area as well as the potential for local innovation that could be derived. 


\section{BCDA partnerships and projects}

From its inception in 2004 the IDC was a key partner in the work of the BCDA in terms of primary funding as well as technical assistance for the design and planning of strategic projects. Overall, the IDC provided BCDA with R20 million towards its establishment and operationalisation as per its project funding cycle. This was supplemented by the municipality in the form of operational funding amounting to R12 million (Wilkins \& Beech, 2016). Throughout its lifespan BCDA continued to function with a lean organisational structure with the aim of unlocking economic development potential in a project-focused and targeted way (LED Network, 2011). The LEDA acknowledged its rural context as both an opportunity and constraint and sought to capitalise on locational factors in the interest of income generation and strategic local economic investment. Further, mindful of the limited availability of technical skills that would be needed to facilitate high level projects, management sought to establish a small specialised team. This team would serve as core project managers who in turn would source technical expertise based on the nature of projects. Functionally, the structure of the operational team was lean with a start-up group of four people. The Chief Executive Officer was responsible for BCDA oversight and performed a project management function in addition to overall management duties. Since the vision of the agency was to be facilitators of economic development, the team focused on enhancing this role by establishing strong networks with key experts and specialists, including government departments, international stakeholders and the private sector. Technical advisory committees comprising of key experts complemented this lean structure and ensured that targeted efforts were put in place to unlock the potential of identified projects. This proved to be a successful operational approach for BCDA (Wilkins \& Beech, 2016). A formal Board of Directors oversaw the work the agency. In recognising its rural nature, the agency also saw provincial and local government departments as implementing partners.

Besides the IDC linkages, there was also a clear recognition on the side of the parent municipality that the BDCA was the economic development agency of the municipality. This was evident in the recognition that its projects received in the formal municipal IDP. It could be argued that the projects were conceptualised in two ways. First, as an innovation linked to contextual factors in the BCRM and second through the municipality's independent community consultation processes in which participatory methods were used to elicit relevant community projects that would address the socio-economic needs of the municipality. In the latter context, projects were then passed onto the agency through municipal consultation processes for realisation and execution (LED Network, 2011; BCDA, 2014). The BCDA team conceded that while this municipal recognition of its role and contribution to local development was positive, support in its area of operations was not necessarily forthcoming from the municipality. This particular lack of support was seen to have impeded the ability of the agency to unlock the potential of its large scale projects (Wilkins \& Beech, 2016). Limited operational funding from the BCRM made it particularly difficult for BCDA to support fully the realisation of high impact projects and it was this funding challenge which perhaps proved to be one of the agency's biggest hurdles. This occurred in spite of the significant leverage that could be garnered by politicians and officials who were associated with these projects. Indeed, the scale and impact of these large scale projects could provide significant benefits, especially much needed jobs for the local communities.

The BCDA team regarded planning alignment with its parent municipality as an important and necessary operational step. As such, they engaged in a conscious process of project and 
planning alignment with key local, district, provincial and national policies in order to ensure strategic alignment beyond local municipality priorities towards a more regional and national government perspective. It was noted that development "in the BCRM cannot be a standalone function of the BCDA; it needs to be aligned to the broader governmental planning" (BCDA, 2011: 11). From a strategic regional development perspective this planning alignment could be regarded as a positive shift because it recognised the wide-ranging spatial impact of projects beyond the territorial boundary of this local municipality.

As a development agency operating in rural South Africa, considerable implementation and institutional challenges emerged. As the agency was owned by the municipality, its governance arrangements were irrevocably tied to the five year cycle of municipal governance. This meant that municipal leadership, governance and institutional memory were closely linked to the prevailing council of the municipality during that political tenure. With the various shifts in the municipal cycles, the agency was impacted by changes in municipal leadership and councillors which in turn affected perceptions of value addition and strategic role of the agency to achieve the municipality's economic vision (Wilkins \& Beech, 2016). The continuity of projects presented another challenge as certain projects that were conceptualised, endorsed and started by one council were not necessarily a priority for new council members. Furthermore, it was not unusual for additional projects to be introduced with the tenure of a new BCRM council (Wilkins \& Beech, 2016). Wilkins and Beech (2016) noted that during the lifespan of the agency, it experienced at least three councils with the first being the most supportive to a large extent because of the comprehensive understanding that it had of the role and value of a municipal owned development agency. Besides political influences, BCDA also experienced shifts in support from senior municipal officials as municipal-agency relationships fluctuated and often were dependent on personal connections and the appreciation of the developmental role and economic development contribution of the agency.

From the onset, BCDA played a number of strategic roles in the local municipal space. These roles included facilitator of change, promoter of local innovation, catalyst for change and strategic networker. As facilitator of change, BCDA saw itself as the initiator of megaLED projects in particular. This activity distinguished the agency from the more social development focus of the municipal LED unit (Table 1). The facilitation of 'mega-LED projects' was seen as a key area of activity for BCDA and a distinguishing feature in its relationship with the parent municipality. Through targeted catalytic interventions, the agency in collaboration with BCRM agreed that its focus would be on exploring the potential of different economic sectors across the municipality. However, in the same vein, it would also attempt to feed into supporting the wider District's socio-economic development challenges, as well as the much broader vision of the municipality in order to expand its value addition to the tourism, services and manufacturing sectors (LED Network, 2011). It was observed that "in order to facilitate future growth in the sector and tackle the unemployment and outmigration challenges, the local skills base needs to be raised and accessibility challenges tackled" (LED Network, 2011: 2). This meant that skills development and facilitation needed to be on the LEDA's agenda since it remained a key inhibiting factor for the further advancement of the area.

As agent for local innovation, BCDA played an important role in the promotion of local innovation. Ferrannini and Canzanelli (2013: 7) emphasise the explicit connection between LEDAs and innovation and argued that LEDAs are well placed to elaborate on innovation. Within the national context the topic of local innovation was starting to emerge as an 
important contributor to the discourse on LED, with considerable effort being placed on how these two fields interlink and how best to further harness potential (Ndabeni et al., 2016). Local innovation was seen as an important opportunity for the promotion of local knowledge products but also as a key factor in local industry development, where LEDAs were potentially seen as a possible conduit for support and partnership. It could be argued that one of the most striking features of the BCDA was its ability to foster innovative thinking within a context of small town and rural development. At the outset of project work the BCDA faced the challenge of the municipality's remote location in the Eastern Cape and identified strategic projects that built on local comparative advantages such as its clean air, agricultural potential and the location of the town in relation to Port Elizabeth, the major city in Eastern Cape. Innovative projects that were identified for this small town municipal area focussed around aviation, solar energy, waste recycling and agriculture. Innovation manifested itself in not only how project conceptualisation took place (e.g. waste to energy recycling ideas to the airfield precinct idea) but also in the creative approach of the team to work within a context of limited capacity and resources.

The aviation project was the BCDA flagship and regarded as an innovative best practice example for a remote small town. This project was conceptualised by capitalising on the unique features of the town and its location. The aviation project was constructed, licensed and endorsed by the national Civil Aviation Authority as a commercial airport in Somerset East and located on the old airfield base in the town (LED Network, 2011: 3). The intention was that the site would be used as a landing strip for commercial planes seeking to connect tourists to local tourism products, most notably the Addo National Park which was $64 \mathrm{~km}$ away. Another initiative was to use this functioning landing strip for an aviation school. Beyond aviation BCDA was instrumental in promoting renewable energy schemes in the area as well as a waste recycling project. Other projects extended to the agriculture sector where the agency played a connecting role through linking commercial partners with local stakeholders. This involved business plan support and technical advisory skills/support, especially for beneficiaries of government's land reform programme (LED Network, 2011: 3). Supported projects included an agriculture park, which involved tunnel farming and the growing of flowers, fruit and vegetables; and a farm project aimed at beneficiaries of land redistribution. Finally, BCDA provided technical advisory and strategic infrastructure support where appropriate and linked the various opportunities with relevant beneficiaries (Okunlola, 2012). The extensive list of projects and innovation by BCDA is notable given the small population size of the local municipality as well as the small project management team at BCDA. The agency enjoyed a range of project funding support from national ministries such as the Department of Trade and Industry, Economic Development Department as well as the IDC. In terms of development facilitation BCDA performed impressively as indexed by estimates that it leveraged investments worth R120 million for a remote area of South Africa. The BCDA team recognised that throughout its operations, they were mindful of the fact that the agency's core task was not necessarily to run a project, but rather to secure the project asset and to ensure that the project asset could then be transferred to the local municipality. Once the project had been transferred to the municipality it was at this stage that the agency would then need to 'walk away'. The handover of projects to the municipality was considered to be a crucial step in the development process.

Arguably, a number of important lessons were learned concerning networks and strategic linkages, especially with regard to provincial and national stakeholders. It was observed that considerable links existed with national partners, albeit similar relations were not necessarily enjoyed across the provincial and political spectrum. In particular, it was felt that strong 
provincial links would have been advantageous especially in the operational context of the Eastern Cape. These provincial linkages were considered to be one of the performance areas that were not a strength of the BCDA management team. Wilkins and Beech (2016) disclosed that these networks were very important given the highly politicised nature of the Eastern Cape Province. They suggest that the absence of provincial support may have contributed towards the lack of funding from the different provincial structures into the local area and specifically through to the development agency. By contrast, the team reflected that they enjoyed considerable success with their own national networks and it was this relationship fact which enabled several development opportunities. Another outstanding attribute of the BCDA team was its ability to establish strategic partnerships, particularly with national and research institutions as well as the private sector (BCDA, 2015). Overall, it was evidenced that since its inception BCDA leveraged significant funding and investment in the area which creating a total of 3250 jobs (Wilkins \& Beech, 2016). Indeed, over a period of three different municipal councils, the agency contributed to R120 million worth of assets that could taken up into municipal assets.

\section{BCDA closure and absorption into the Cacadu District Development Agency}

Notwithstanding the above positive contributions to the local economy of the BCRM the decision was made to close down the local agency and instead to integrate its key projects into the work of the development agency of the District Municipality, which at the time was known as the Cacadu Development Agency (CDA). By January 2016 the BCDA was fully merged into the CDA. This was seen to be part of a broader District process wherein the District Municipality decided to focus on targeting strategic local economic projects across the district. An interview with the CDA in March 2016 revealed that this process formed part of a longer term decision taken in 2012 where the District resolved to engage with the BCRM on absorbing the agency into the district LED platform (Mvoko, 2016a). After consideration of its budgetary responsibilities, the BCRM decided that it would continue its budgetary allocation for the period 2014/2015, but after this period they envisaged changes within its contribution and support to its local agency. It was agreed that while the role of an agency made sense, it was better placed to support a District-wide agency, namely the CDA. In this way, strategic projects in Somerset East would still receive municipal support and attention but as part of a broader mandate of work through the implementation modality of CDA (BCRM, 2016; Mvoko, 2016a, 2016b).

Besides the strategic location of the agency at District level it was argued that the local municipality could no longer afford the agency and therefore would only be in a position to fund the agency for the final six months period, namely July to December 2014. This was deemed unfortunate and raises the issue of value addition for the local municipality since the agency was closed in spite of its substantial contribution to the local development context of this rural municipality. This value addition was recognised by the District LED team as more in line with where the District agency was going with its project implementation strategy. Hence, in January 2015 when the BCDA "ceased to exist", their strategic projects and strong project management team became incorporated as part of the implementation team of the District municipality.

In respect of the closure of the BCDA, Mvoko (2016a) commented that the challenge of the closure of a development agency raises another often overlooked procedural issue namely the actual procedure for agency close down. According to Mvoko (2016a, 2016b) the existing 
law did not allow for a six month closing down period of a development agency. Procedurally this process involved a considerable administrative challenge for the local municipality. Since the greater part of BCDA's work involved development facilitation as opposed to project implementation the benefit to the municipality in terms of multi-million rand external investment into the area was not necessarily visible in the form of returns to the local municipality. The unintended consequence of this decision on the side of the municipality also meant that in some cases projects could not run their full cycle and instead had to be ended midway (Mvoko, 2016a). In order to ensure a smooth transition into the District agency, a process was undertaken to determine the scale of its agency operations. It was also decided that CDA would address catalytic project development across all the local municipalities, including Blue Crane Local Municipality. Recognising the experience of the BCDA team, it was agreed that the former Acting CEO and Project Manager would be integrated into the District agency. The reason for this decision was to ensure that the District Agency would benefit from the extensive experience of the BCDA team. In doing so, it would also ensure that they would be easily able to apply highly specialised project facilitation skills to catalytic interventions across the District. With the above in mind, the expertise and knowledge sharing was to be of benefit to more than one local municipality as additional local municipalities stood to gain from this extensive expertise. From a District perspective, CDA was established to look at catalytic projects that would have a district wide impact. It also meant that development projects could also potentially cut across boundaries of local municipalities (Mvoko, 2016a).

The political support of key economic development players in the province was viewed as instrumental to the success of CDA and these linkages were well established and proved beneficial from the onset. These linkages also impacted on further developments taking place in selected projects which initially were part of the project package of BCDA. With the political support behind the CDA, one of the first projects that were funded through the efforts of the District was the completion of the airfield project in Somerset East. Not only was relevant funding secured for this but also ancillary projects were supported. Additional projects included the tarring of the road between the airfield and the tourist town of Addo. This decision not only ensured better connectivity for communities in Addo and Somerset East, but also for the surrounding tourism industry which could benefit. Another project that received support was the promotion of historical monuments as potential heritage tourism assets. To further capitalise on the airfield project, an industrial park was zoned within the airport precinct. The District was in the process of seeking funding from different national stakeholders for the bulk infrastructure needed to operationalise this industrial park. It was observed that a 'precinct approach' was explored together with the National Treasury. Funding was sourced from international companies for energy and waste projects that could potentially be located within the same industrial park (Mvoko, 2016b).

According to District officials the process of the dissolution of development agencies was not without institutional and legal challenges. In the case of the BCDA, the process was met with considerable delays. Partly this challenge was attributed to the fact that the BCDA was established in terms of a by-law and in order to repeal this, due legal process was needed, which required considerable effort and time (Mvoko, 2016a). While this legal process was underway, the District and its experienced implementation team were concerned with unlocking development project potential across the district on a range of projects. 


\section{Conclusion}

Place-based development interventions are gaining increasing attention by a community of urban planners, economic geographers, and LED practitioners (Rogerson, 2014; RodriguezPose \& Wilkie, 2017). In the international context there is mounting interest in the role and potential of LEDAs in place-based development. One focus for LEDAs has been in peripheral regions in order to support improved economic development futures (Lawrence \& Rogerson, 2018). In South Africa LEDAs have moved strongly onto the policy radar as existing LED interventions have proven disappointing and not least in terms of their impacts for redressing massive spatial inequalities. The poor performance of LED in South Africa has been especially so in the context of less well-resourced municipalities in small towns. In order to support struggling local governments seeking to improve prospects for local development the national government, through the activities of the Industrial Development Corporation, supported the growth of LEDAs in South Africa (Lawrence, 2013; Khambule, 2018). LEDAs operate as entities with public interest and accountability but apply private sector tools and strategies. In the South African context they are considered a specialized institution which is required to fill a gap between the crafting and implementation of development plans and so function as a delivery tool which is "owned by the municipality to coordinate and manage public resources, potential investors and regional investment opportunities in accordance with the identified development objectives" (Nel, 2017: 6).

The objective in this study was to investigate the evolution and operational challenges of a small town LEDA in South Africa. Using documentary sources in terms of annual reports and internal documents as well as rich stakeholder interviews an analysis was undertaken of the BCDA and its activities in Somerset East and surrounds in Eastern Cape. It was shown that the BCDA has been innovative in its development initiatives undertaken during the period 2004-2014 for this small town and its surrounding rural area. In analysing the projects and activities of BCDA it is evident considerable effort was put in place to identify catalytic opportunities and to support the unlocking of these projects through development facilitation, feasibility and project management. The evidence from this case study demonstrates that despite many successes, development agencies in South Africa have a strong dependence on the parent municipality which often determine the future direction and sustainability of LEDAs. Arguably, these decisions on future directions may not necessarily be optimal for the leadership of a LEDA as they often are taken outside of the organisation. In addition, it was disclosed that LEDAs often have a particular life cycle, interconnected to local government and that their future is interwoven with the political and administrative context of local government and the environment within which the LEDA operates. Indeed, the BCDA experience highlights the potential lifespan limits of a development agency. It might be argued that the dissolution and merger of BCDA was the consequence of it outliving its contribution to the local municipality's economic development vision. This said, the closure of BCDA, in spite of its many successes, reveals the importance of not only ensuring the visibility of projects but also the perceived ownership and benefits accrued to the municipality and the value placed on these projects. The experience of BCDA discloses that political support provided a vital catalyst for development and at times proved to be invaluable in unlocking the necessary blockages faced by the project implementation teams as was demonstrated by the airfield project.

In the final analysis, this LEDA case study highlights a number of important key policyrelated issues that impact development agencies specifically in a small town context (Lawrence, 2018). Of note are the importance of networks for securing support and resources 
for projects, the critical role of securing upfront funding of projects and securing political buy-in. Indeed, the strong impress of the political context within which agencies operate - at least in South Africa - cannot be underestimated. In the example of Somerset East the political context was shown to exert a direct bearing on the support received at municipal level for BCDA as well as unfolding project implementation progress. Arguably, a balance is needed between political support and project implementation progress that may take place outside of political support process. Another issue is that project ownership and handover must be clearly outlined and agreed upon prior to the development of a project. This should not be a once off agreement but rather be continuously reinforced during the conceptualisation, design and implementation of projects. Finally, the experience of Somerset East confirms that the success of any development agency is contingent upon the establishment of partnerships amongst stakeholders, a committed and visionary leadership, an entrepreneurial approach undertaken with the maintenance of public interest, a clear strategic vision for local development, and the appropriate mobilisation and valorisation of local development assets (Nel, 2017).

Faith Lawrence, University of Johannesburg, School of Tourism \& Hospitality, College of Business and Economics, Johannesburg, South Africa (faith.lawrence@gtz.de)

Christian M. Rogerson, University of Johannesburg, School of Tourism \& Hospitality, College of Business and Economics, Johannesburg, South Africa (crogerson@uj.ac.za)

\section{Acknowledgements}

Thanks to journal referees for inputs to an earlier version of this paper.

\section{References}

Barca, F., McCann, P. \& Rodriguez-Pose, A. (2012) The case for regional development intervention: Placebased versus -place-neutral approaches. Journal of Regional Science, 52, pp. 13-152. DOI: $10.1111 / \mathrm{j} .1467-9787.2011 .00756 . \mathrm{x}$

Bateman, M. (2012) Local economic development in Latin America. A study of the role of the UNDP-supported LEDAs in promoting sustainable local economic and social development. Rome, International Links and Services for Local Economic Development.

Blakely, E. \& Leigh, N. (2010) Planning local economic development: Theory and practice. Newbury Park, California, Sage.

Blue Crane Development Agency (2008a) Engagement options for the development of municipal assets. Internal document. Somerset East, BCDA.

Blue Crane Development Agency (2008b) Discussion document for establishment of a development forum for BCRM Towns. Internal document. Somerset East, BCDA.

Blue Crane Development Agency (2011) Policy document: Strategy. Internal document. Somerset East.

Blue Crane Development Agency (2014) Annual report 2013/2014. Internal document. Somerset East.

Blue Crane Development Agency (2015) Report of Director Planning. Diagram of partner landscape. Internal document. Somerset East.

Blue Crane Route Municipality (2016) Integrated development plan review 2015/2016. Somerset East.

Canzanelli, G. (2008) Territorial economic development and human development: The ILS LEDA approach. Working paper no.8. Brussels, International Link and Services for Local Economic Development Agencies.

Canzanelli, G. (2009) State of the Art review on local economic development agencies. Working paper no.12. Brussels, International Link and Services for Local Economic Development Agencies.

Canzanelli, G. (2011a) Evaluation of local and territorial development agencies for human development. Working paper no.15. Brussels, International Link and Services for Local Economic Development Agencies. 
Canzanelli, G. (2011b) Models of territorial development agencies in Europe and in the World. Working paper no.13. Brussels, International Link and Services for Local Economic Development Agencies.

Clark, G., Huxley, J. \& Mountford, D. (2010) Organising local economic development: The role of development agencies and companies. Paris, OECD. DOI: 10.1787/9789264083530-en

Ferrannini, A. \& Canzanelli, G. (2013) The role of local economic development agencies for innovation. Working paper no.20. Brussels, International Link and Services for Local Economic Development Agencies.

International Link and Services for Local Economic Development Agencies (2009) Local economic development agencies for governance and internationalization of local economies and human development. Brussels.

Khambule, I. (2018) The role of local economic development agencies in South Africa's developmental state ambitions. Local Economy. DOI: 10.1177/0269094218766459

Lawrence, F. (2013) The role of local economic development agencies in the South African economic development landscape. Urban Forum, 24(4), pp. 523-541. DOI: 10.1007/s12132-013-9195-z

Lawrence, F. (2016) Local economic development agencies - pushing boundaries and addressing change: The case of South Africa's Aspire (Amathole District Economic Development Agency) during its maturation phase. Local Economy, 31(1-2), pp. 83-94. DOI: 10.1177/0269094215621873

Lawrence, F. (2018) Local economic development agencies in South Africa: Evolution, organisation and progress. Doctoral thesis. Johannesburg, University of Johannesburg.

Lawrence, F. \& Rogerson, C. M. (2018) Local economic development agencies and place-based development: Evidence from South Africa. Bulletin of Geography: Socio-Economic Series, 41, pp. 29-43. DOI: $10.2478 /$ bog-2018-0024

LED Network (2011) Blue Crane Development Agency in Eastern Cape. Case study. Pretoria, South African Local Government Association and the Industrial Development Corporation.

Malefane, S. R. (2011) The strategic position and intergovernmental relations roles of South Africa's local economic development agencies. Journal of Public Administration, 46(3), pp. 977-993.

Malefane, S. R. \& Khalo, T. (2010) The role of local government in mitigating the impact of the recession. Journal of Public Administration, 45(1), pp. 133-144.

Meyer-Stamer, J. (2007) Designing a regionald agency: Options and choices. Duisburg, Mesopartner Working Paper Series.

Mountford, D., (2009) Organising for local development: The role of local development agencies. Paris, OECD.

Muguira, A. M. (2006) The socio-economic impact of local economic development agencies (LEDAs) in Mozambique: A Case study of LEDAs in Manica and Sofala. Masters Thesis. Maputo, Catholic University of Mozambique.

Mvoko, G. (2016a) Interview by F. Lawrence with CEO of Cacadu Development Agency, 3 Mar. 2016, Port Elizabeth.

Mvoko, G. (2016b) Interview by F. Lawrence with CEO of Cacadu Development Agency, 26 Oct. 2016, Port Elizabeth.

Ndabeni, L. L., Rogerson, C. M. \& Booyens, I. (2016) Innovation and local economic development policy in the global South: New South African perspectives. Local Economy, 31(1-2), pp. 299-311. DOI: $10.1177 / 0269094215621865$

Nel, E. \& Rogerson, C. M. (eds.) (2005) Local economic development in the developing world: The experience of Southern Africa. New Brunswick, NY, Transaction.

Nel, E. \& Rogerson, C. M. (2007) Evolving local economic development policy and practice in South Africa with specific reference to smaller urban centres. Urban Forum, 18(2), pp. 1-11.

Nel, E. \& Rogerson, C. M. (2016a) Re-engaging with spatial economic development: The recent experience of regional and local economic development in South Africa. Local Economy, 31(1-2), pp. 3-8. DOI: $10.1177 / 0269094215623726$

Nel, E. \& Rogerson, C. M. (2016b) The contested trajectory of applied local economic development in South Africa. Local Economy, 31(1-2), pp. 109-123. DOI: 10.1177/0269094215623729

Nel, E., Binns, T. \& Bek, D. (2009) Misplaced expectations? The experience of applied local economic development in post-apartheid South Africa. Local Economy, 24(3), pp. 227-240. DOI: $10.1080 / 02690940902895877$

Nel, S. (2017) The development agency concept. Paper presented at the National Local Economic Development Conference, Pretoria, 10 November. Typescript.

Okunlola, A.S. (2012) Local economic development, agriculture and livelihoods. Doctoral thesis. Bellville, University of the Western Cape.

Rodriguez-Pose, A. \& Wilkie, C. (2015) Conceptualising equitable economic growth in cities. Brussels, Cities Alliance. 
Rodriguez-Pose, A. \& Wilkie, C. (2017) Revamping local and regional development through place-based strategies. Cityscape: A Journal of Policy Development and Research, 19(1), pp. 151-170.

Rogerson, C. M. (2010) Local economic development in South Africa: Key strategic challenges. Development Southern Africa, 27, pp. 481-495. DOI: 10.1080/0376835X.2010.508580

Rogerson, C. M. (2011) Tracking local economic development policy and practice in South Africa, 1994-2009. Urban Forum, 22, pp. 149-168. DOI: 10.1007/s12132-011-9113-1

Rogerson, C. M. (2014) Reframing place-based economic development in South Africa: The example of local economic development. Bulletin of Geography: Socio-Economic Series, 24, pp. 203-218. DOI: $10.2478 /$ bog-2014-0023

Rogerson, C. M. (2018) Innovation-driven local economic development: In search of best practice implementation for South Africa. Euroeconomica, 37, pp. 15-28.

Rogerson, C. M. (2019) Revamping local economic development policy in South Africa. In: J. Knight \& C. M. Rogerson (eds.) Geography of South Africa: Contemporary Changes and New Directions, Cham, Springer International, pp. 253-259. DOI: 10.1007/978-3-319-94974-1_27

Rogerson, C. M. \& Nel, E. (2016a) Redressing inequality in South Africa: The spatial targeting of distressed areas. Local Economy, 31(1-2), pp. 28-41. DOI: 10.1177/0269094215618595

Rogerson, C. M. \& Nel, E. (2016b) Planning for local economic development in spaces of despair: Key trends in South Africa's distressed areas. Local Economy, 31(1-2), pp. 124-141. DOI: $10.1177 / 0269094215623731$

Rogerson, C. M. \& Rogerson, J. M. (2010) Local economic development in Africa: Global context and research directions. Development Southern Africa, 27, pp. 465-480. DOI: 10.1080/0376835X.2010.508577

Rogerson, C. M. \& Rogerson, J. M. (2011) Improving the business environment for local economic development in South Africa. Journal of Public Administration, 46, pp. 994-1009.

Rogerson, C. M. \& Rogerson, J. M. (2012) Business development and local economic development in South Africa: Addressing the disconnect. Acta Academica, 44(2), pp. 41-69.

Todes, A. \& Turok, I. (2018) Spatial inequalities and policies in South Africa: Place-based or people-centred?. Progress in Planning, 123, pp. 1-31. DOI: 10.1016/j.progress.2017.03.001

Turok, I. \& Visagie, J. (2018) Inclusive urban development in South Africa: What does it mean and how can it be measured? Working Paper 2018/52. Brighton, University of Sussex Institute of Development studies.

UNDP, ILO, UNOPS, EURADA \& Italian Ministry of Foreign Affairs (2003) Local economic development agencies. International Co-operation for human development, economic democracy and poverty reduction.

Venter, M. (2014) From lip-service to service delivery in local economic development: Guidelines to set up an agency for action. Journal of Economic and Financial Sciences, 7(3), pp. 721-736.

Walaza, K. (2017) The national framework for local economic development: Creating innovation driven local economies. Paper presented at the National Local Economic Development Conference, Pretoria, 10 November. Typescript.

Wilkins, C. \& Beech, R. (2016) Joint interview by F. Lawrence with former CEO and Project Managers of Blue Crane Development Agency, 2 Mar. 2016, Somerset East. 